\title{
Use of green tea for the production of sponge cake
}

\author{
Irina Timoshenkova ${ }^{1,{ }^{*}}$,Elena Moskvicheva ${ }^{1}$, Ekaterina Fedinishina ${ }^{1}$, Maya Bernavskaya ${ }^{1}$ \\ ${ }^{1}$ Graduate School of biotechnology and food science, Peter the Great St.Petersburg Polytechnic University (SPbPU), Polytechnicheskaya \\ 29, 195251 St. Petersburg, Russia
}

\begin{abstract}
The problem of micronutrient enrichment and the improvement of the technology for the production of flour confectionery products is relevant. The aim of the work is to study the possibility of using green tea to create sponge cake. The objects of study were Sencha green tea powders (Japan and China), wheat flour, their mixtures in different percentages and sponge cake. According to the obtained experimental data green tea powders is characterized by low humidity $(5.0 \pm 0.5) \%$ and high acidity $(5.8 \pm$ $0.2) \%$. The content of flavonoids in tea is $(52.5 \pm 0.5) \mathrm{mg} / 100 \mathrm{~g}$, the amount of $\beta$-carotene $-(3.2 \pm 0.5)$ $\mathrm{mg} / 100 \mathrm{~g}$. The following physical-chemical and technological parameters were determined in the finished products: moisture, porosity and swelling. Rheological characteristics of finished products were determined by the device "Structure meter ST-1M". During storage of products the dynamics of microbiological indicators and water activity over 10 days was determined. The results objectively proved the possibility of using green tea for the production of flour confectionary products. Finished products had high organoleptic and rheological properties. The use of green tea enriched the product with phosphorus, iron, $\beta$-carotene and B vitamins.
\end{abstract}

\section{Introduction}

Flour confectionery products are traditionally in demand among consumers. They are an important part of the diet of modern people. It is known that dough products are characterized by a rather high content of carbohydrates and fats. But the lack of biologically active substances significantly reduces the nutritional value of the finished product. It has become relevant to enrich the recipes of flour confectionery products with components of plant origin containing physiologically significant micronutrients and have good digestibility $[1,2]$.

Green tea is a source of trace elements vitamins and other physiologically active compounds. It is well known by its antibacterial activity and antioxidant properties. In the foreign literature the issues of the chemical composition of green tea and its beneficial effects on the human body are observed $[3,4]$.

A number of foreign authors have shown the positive effect of green tea supplements on drinks and culinary products quality and food technology [5]. Yedygovoy S.N. studied the effect of green tea on the technological properties and physico-chemical parameters of yeast dough. The positive effect of the additive on the organoleptic and nutritional value of wheat bread is shown. It has been established that the addition of green tea infusion slows down bread staling [6]. A study by Phongnarisorn B., Orfila C., Holmes M. showed the physiological significance of green tea in the biscuit recipe [7].

It should be noted that infusions and extracts of green tea are used as an enrichment agent. Their use in the cooking of flour confectionery products is the problem for manufacturers because additional liquid components can adversely affect such parameters as viscosity and elasticity of the dough. They could complicate the process and lead to the decrease of finished product properties.

For sponge cake semi-finished product with normalized moisture content in the range of $25-29 \%$, the use of green tea powder is preferable. The introduction of herbal powders into dough products can also have a significant impact on the technological process and the physicochemical parameters of the finished product. It greatly influences the structural and mechanical properties of the dough products, their moisture content and shelf life [7]. An analysis of scientific literature has shown that the possibility of using green tea powder as an enrichment agent for flour confectionery products has not been sufficiently studied. There are no studies on the effect of tea varieties on technological parameters and consumer qualities of the finished product.

\section{Materials and Methods}

This work is dedicated to the studies of samples of flour and green tea mixture of Sencha variety from two different manufacturers (in the ratio of 5\%,10\%, 12\% and $15 \%$ by weight of flour) Sencha Fukamushi (Japan) and Sencha (Shu Xiang Lu) (China) and basic sponge cake with the addition of green tea powder (in the ratio of $5 \%, 10 \%, 12 \%$ and $15 \%$ by weight of flour). As a control sample the basic sponge cake is selected. For

\footnotetext{
* Corresponding author: itimoshenkova@spbstu.ru
} 
flour and tea the main indicators that fully characterize their quality and functional properties according to standard methods were chosen. As a basis quantitative determination, flavonoid contents in selected plant extracts were determined using aluminium chloride in a colorimetric method. The results were derived from the calibration curve [8].

Moisture content (AOAC method 977.11), crude protein Kjeldahl's (AOAC method 955.04), crude fat Soxhlet (AOAC method 960.39), titratable acidity (AOAC method 942.15), carotenoids (AOAC method 941.15), fatty acids (AOAC method SMPR 2012.13) was determined [9]. Carbohydrate was calculated by difference: carbohydrate $=[100-$ (moisture + crude protein + crude fat)].

Water-binding (WBC) and fat-binding (FBC) capacity of flour and green tea was determined by centrifugation of a water-flour and fat-flour suspension for 15 minutes at a rotation speed of $3000 \mathrm{rpm}$ [1].

The degree of rise sponge cake was calculated by the change in the average height of the baked product in relation to the original height of the dough piece.

The product sticks were determined by the change in mass after baking, relatively initial mass of the dough.

The density of the product was specified according to its volume and mass. The porosity was specified according to GOST 5669 [10].

Swelling of the crumb was determined by the ratio of the volume of sediment in the aqueous suspension and the solids content in the cupcake.

The rheological characteristics of the sponge cake samples were formed using a Structometer- ST-1M of MPF9, the firm Radius (Russia). The device allows determining the deformation crumb characteristics (general, plastic and elastic deformation).

Control and test cupcake samples were stored for 13 days at a temperature $(18 \pm 2)^{\circ} \mathrm{C}$. During storage water activity (Aqulab Pawkit) and microbiological indicators have changed.

The quantity of yeast and mold (AOAC method 997.02), Coliform and Eschericchia coli (E-coli) (AOAC method 991.14), Aerobic Plate (APC kfu/g) (AOAC method 986.32), Staphylococcus aureus (AOAC method 975.55) was determined [9].

Microbiological studies were carried out in accordance with the requirements of the MI 4.2.1847 [11] and TP CU 021/2011 [12].

Minerals were determined by the method of James [13] - Iron (Fe), Calcium (Ca), Magnesium (Mg), Sodium (Na) and Potassium (K) using spectrophotometer (UNICO model 2802). Absorbance was recorded and a standard curve was plotted. Meanwhile, phosphorus (P) content was determined using colorimetric method. Results were expressed in $\mathrm{mg} / 100 \mathrm{~g}$ sample.

The percentage of Vitamin A (AOAC method 974.29), Vitamin B1 (AOAC method 942.23), Vitamin $\mathrm{B}_{2}$ (AOAC method SMPR 2015.003), Vitamin C (AOAC method 967.21), Vitamin $\mathrm{B}_{4}$ (AOAC method SMPR 2012.005), Vitamin PP (AOAC method SMPR 2012.006) was determined [9].
Statistical analyses were carried out using the Statgraphics Centurion 18 for analyses of variance (ANOVA). Three replications were performed for all the analyses.

\section{Results and Discussion}

The results of the determination of physic-chemical, biochemical and technological parameters of flour and tea are shown in Table 1.

Table 1. The results of studies of green tea and wheat flour.

\begin{tabular}{|c|c|c|c|c|}
\hline \multirow{2}{*}{$\begin{array}{c}\text { Name of } \\
\text { indicato } \\
\mathbf{r}\end{array}$} & $\begin{array}{c}\text { Unit of } \\
\text { measurem } \\
\text { ent }\end{array}$ & $\begin{array}{c}\text { Wheat } \\
\text { flour }\end{array}$ & $\begin{array}{c}\text { Sencha } \\
\text { Fukamush } \\
\mathrm{i}\end{array}$ & $\begin{array}{c}\text { Sencha } \\
\text { (Shu } \\
\text { Xiang } \\
\text { Lu) }\end{array}$ \\
\hline moisture & $\%$ & $14.5 \pm 0.4$ & $4.5 \pm 0.3$ & $5.5 \pm 0.1$ \\
\hline Acidity & ${ }^{\circ} \mathrm{T}$ & $4.0 \pm 0.2$ & $5.6 \pm 0.2$ & $6.0 \pm 0.2$ \\
\hline $\begin{array}{c}\text { Flavonoi } \\
\text { d content }\end{array}$ & $\mathrm{mg} / 100 \mathrm{~g}$ & $\begin{array}{c}\text { Not } \\
\text { found }\end{array}$ & $52.5 \pm 0.3$ & $6.3 \pm 0.3$ \\
\hline $\begin{array}{c}\text { B- } \\
\text { carotene } \\
\text { content }\end{array}$ & $\mathrm{mg} / 100 \mathrm{~g}$ & $\begin{array}{c}\text { Not } \\
\text { found }\end{array}$ & $3.71 \pm 0.05$ & $\begin{array}{c}2.86 \pm 0.0 \\
5\end{array}$ \\
\hline $\begin{array}{c}\text { water } \\
\text { binding } \\
\text { capacity }\end{array}$ & $\%$ & $82.4 \pm 0.5$ & $142.3 \pm 0.5$ & $\begin{array}{c}138.2 \pm 0 . \\
\text { fat- } \\
\text { binding } \\
\text { capacity }\end{array}$ \\
\hline
\end{tabular}

An analysis of the data obtained showed that green tea can be recommended in the high-value sponge cake production. However green tea powder added to a sponge cake recipe can affect its quality and nutritional value. So it was found that the mass fraction of moisture in green tea powder is on average three times less than the mass fraction of moisture of flour and the acidity of green tea powder is twice as high as flour. The mixture of these components can affect the structure and porosity of the semi-finished product.

The purpose of this research was the studying of flavonoids content in green tea. When ingested with food this group of physiologically active substances influence the activity of enzymes. They neutralize the action of free radicals, protect cells from destruction thus preventing premature aging of the body and protect against the development of atherosclerosis. It is also proven that flavonoids are able to change the reaction of the human body to allergens, carcinogens and viruses.

It is established that the chemical composition of tea depends on the variety. The content of flavonols in Sencha Fukamushi green tea 13 times exceeds the amount of flavonols in Shu Xiang Lu green tea. Based on the data obtained, Sencha Fukamushi green tea can be considered as a source of flavonoids.

The study revealed a high content of $\beta$-carotene in tea (from 2.9 to $3.8 \mathrm{mg}$ ). At the same time the physiological need for $\beta$-carotene for adults is $5 \mathrm{mg} /$ day. For the best digestion of $\beta$-carotene it is recommended to use finely processed foods rich in fats such as butter, cream and curd creams in confectionery products. 
The water-binding and fat-binding properties of green tea are higher than those of wheat flour. It can be assumed that when a certain amount of green tea is added to the sponge cake semi-finished product, its water-absorbing abilities change. This can affect the structural and mechanical properties of the crumb. In this regard the next stage of the study was to determine the technological characteristics of mixtures for baking flour and green tea products. The water-binding and fatbinding abilities of flour and green tea mixtures and the generalized organoleptic index of sponge cake products with the addition of green tea from 5 to $20 \%$ to flour in increments of $5 \%$ were investigated.

It was found that the water-binding ability of a mixture of flour and green tea powder grows with increasing concentration of the latter. In addition, there is an advantage in the mixture with green tea "Sencha Fukamushi" (Japan). The fat-binding ability of a mixture of flour and tea depends on the amount of the latter and the highest values are achieved at a concentration of 10 $12 \%$ by weight of flour (Fig. $1-2$ ).

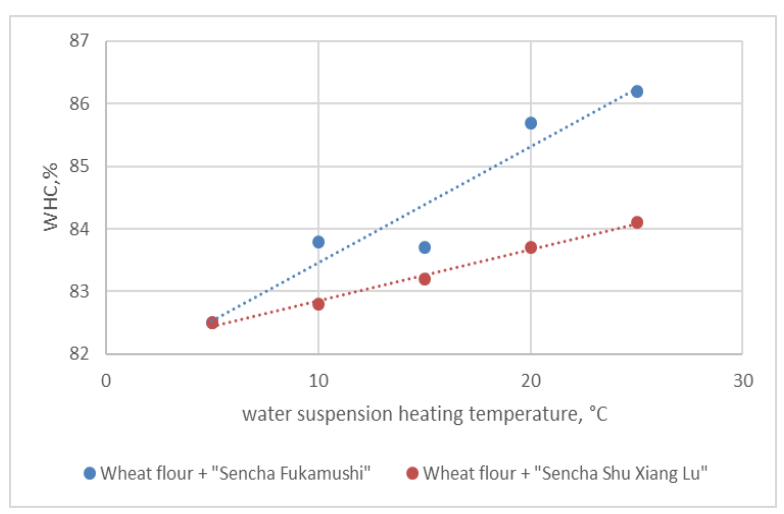

Fig. 1. WBC of mixtures green tea and wheat flour.

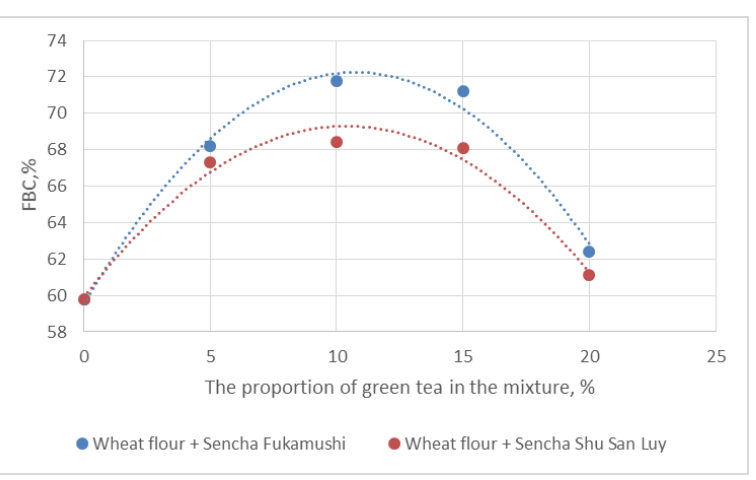

Fig. 2. FBC of mixtures green tea and wheat flour.

As a result of mathematical processing of the obtained experimental data regression equations were established. They characterize the dependences of WBC and $\mathrm{FBC}$ of a mixture of green tea and flour on the proportion of green tea in the mixture $\left(\mathrm{Y}_{\mathrm{J}}{ }^{\mathrm{WBC}}, \mathrm{Y}_{\mathrm{K}}{ }^{\mathrm{WBC}}\right.$, $\mathrm{Y}_{\mathrm{J}}^{\mathrm{FBC}}, \mathrm{Y}_{\mathrm{K}}{ }^{\mathrm{FBC}}$ ) (Table 2). The adequacy of the obtained regression equations to a real experiment is confirmed by the calculated values of the Fisher criterion which are higher than the tabulated value for given degrees of freedom $(\mathrm{F} 0.05=7.71)$.
Table 2. Regression statistics of the dependence of WBC mixture of green tea and flour on the concentration of green tea.

\begin{tabular}{|c|c|c|c|}
\hline Regression equation & $\mathbf{R}$ & $\mathbf{R}^{\mathbf{2}}$ & $\mathbf{F}_{\mathbf{0 . 0 5}}$ \\
\hline $\mathrm{Y}_{\mathrm{J}}{ }^{\mathrm{WBC}}=82.3+0.2 \mathrm{x}$ & 0.98 & 0.96 & 96 \\
\hline $\mathrm{Y}_{\mathrm{K}}{ }^{\mathrm{WBC}}=82.4+0.1 \mathrm{x}$ & 0.99 & 0.99 & 396 \\
\hline $\mathrm{Y}_{\mathrm{J}}{ }^{\mathrm{FC}}=-0.11 \mathrm{x}^{2}+2.37 \mathrm{x}+59.53$ & 0.99 & 0.98 & 196 \\
\hline $\mathrm{Y}_{\mathrm{K}}{ }^{\mathrm{FBC}}=-0.09 \mathrm{x}^{2}+1.81 \mathrm{x}+59.92$ & 0.98 & 0.97 & 129 \\
\hline
\end{tabular}

Results of the studies show that green tea does not have the baking properties of wheat flour. However it can be recommended for use in the flour confectionery industry for example as an additional component to create functional products, pastries without high gluten content such as sponge cake. This led to the development of the recipe (Table 3) and the sponge cake dough technology with the addition of green tea in the amount of $12 \%$.

Table 3. Recipe for green tea sponge cake.

\begin{tabular}{|c|c|c|c|}
\hline $\begin{array}{c}\text { Name of } \\
\text { raw } \\
\text { materials }\end{array}$ & $\begin{array}{c}\text { Mass } \\
\text { fraction of } \\
\text { solids, } \%\end{array}$ & \multicolumn{2}{|c|}{$\begin{array}{c}\text { Raw material consumption per } \\
\mathbf{1} \text { kg of semi-finished product, } \mathbf{g}\end{array}$} \\
\cline { 3 - 4 } & actually & in solids \\
\hline $\begin{array}{c}\text { Premium } \\
\text { wheat } \\
\text { flour }\end{array}$ & 85.5 & 222 & 190.00 \\
\hline Green tea & 95.5 & 27 & 25.77 \\
\hline $\begin{array}{c}\text { Potato } \\
\text { starch }\end{array}$ & 80 & 52 & 41.90 \\
\hline $\begin{array}{c}\text { Granulated } \\
\text { sugar }\end{array}$ & 99.85 & 317 & 316.98 \\
\hline $\begin{array}{c}\text { Egg } \\
\text { whites }\end{array}$ & 12 & 310 & 37.14 \\
\hline Egg yolks & 46 & 206 & 94.92 \\
\hline Total & 38.71 & 1000 & 387.10 \\
\hline
\end{tabular}

A feature of the technology for the production of sponge cake with green tea was the "separate" introduction of eggs. At the first stage the yolks were separated from the egg whites. For Italian meringue whipped egg whites were brewed with syrup at a temperature of $120^{\circ} \mathrm{C}$. In this case finely porous stable foam forms and it makes the sponge cake frame. The yolks were combined with whipped egg whites than the main ingredients were added.

It was found that the upper crust of the finished sponge cake is convex smooth thin and soft the cut is smooth the crumb is dense and not crumbling while small sections of larger pores are noticeable.

The results of determining the physic-chemical and technological parameters of green tea sponge cake are shown in Table 4. 
Table 4. The indicators of the sponge cake.

\begin{tabular}{|c|c|c|c|c|}
\hline \multirow[b]{2}{*}{ Indicator } & \multirow{2}{*}{$\begin{array}{c}\text { Unit of } \\
\text { measure } \\
\text { ment, } \\
\%\end{array}$} & \multicolumn{3}{|c|}{ Indicator value } \\
\hline & & $\begin{array}{c}\text { Basic } \\
\text { sponge } \\
\text { cake } \\
\text { (control } \\
\text { sample) }\end{array}$ & $\begin{array}{c}\text { Sencha } \\
\text { Fukamu } \\
\text { shi green } \\
\text { tea } \\
\text { sponge } \\
\text { cake }\end{array}$ & $\begin{array}{c}\text { Sponge } \\
\text { cake } \\
\text { with } \\
\text { green } \\
\text { tea } \\
\text { "Shu } \\
\text { Xiang } \\
\text { Lu" }\end{array}$ \\
\hline Dough lift & $\%$ & $79.1 \pm 0.2$ & $82.1 \pm 0.2$ & $\begin{array}{c}80.3 \pm 0 . \\
3\end{array}$ \\
\hline Oven loss & $\%$ & $21.0 \pm 0.3$ & $19.8 \pm 0.3$ & $\begin{array}{c}20.6 \pm 0 . \\
2\end{array}$ \\
\hline Moisture & $\%$ & $\begin{array}{c}16.62 \pm 0 . \\
2\end{array}$ & $19.6 \pm 0.2$ & $\begin{array}{c}18.3 \pm 0 . \\
4\end{array}$ \\
\hline $\begin{array}{l}\text { Crumb } \\
\text { density }\end{array}$ & $\mathrm{g} / \mathrm{cm}^{3}$ & $0.37 \pm 0.3$ & $0.32 \pm 0.3$ & $\begin{array}{c}0.35 \pm 0 . \\
2\end{array}$ \\
\hline $\begin{array}{l}\text { Crumb } \\
\text { porosity }\end{array}$ & $\%$ & $70.1 \pm 0.1$ & $75.7 \pm 0.1$ & $\begin{array}{c}71.5 \pm 0 . \\
1\end{array}$ \\
\hline $\begin{array}{l}\text { Swelling } \\
\text { crumb }\end{array}$ & $\mathrm{ml} / \mathrm{g}$ & $7.8 \pm 0.2$ & $8.7 \pm 0.3$ & $8.6 \pm 0.3$ \\
\hline
\end{tabular}

It was found that the oven-loss of semi-finished products was less than $21 \%$ that means small losses during baking. The degree of rise of dough for sponge cake with green tea during baking is high and it can be associated with the technology of separate preparation of the dough.

The moisture index of a sponge cake with green tea baked by technology of separate introduction of eggs and brewing egg whites with hot syrup is higher than the standard moisture of the sponge cake. Moreover the bakery product made with the green tea mixture is characterized by a lower density of the crumb.

The porosity and swelling of a product with green tea is comparable to a classic sponge cake therefore the sample will be easily soaked in syrup and keep its shape.

It should be mentioned that the type of tea greatly affects these indicators. Sponge cake baked with the addition of Sencha Fukamushi tea has the best quality indicators.

Depending on the raw materials flour confectionary products, including those with functional components, have various rheological characteristics. It depends on many factors such as the chemical composition of the components, temperature, duration and intensity of thermal process. In addition flour confectionary products are made from organic raw materials, therefore during production and storage, biochemical, microbiological, colloid-chemical processes that affect the structural and mechanical properties of finished products can take place in them. The study of the rheological characteristics of new types of flour confectionery products will make it possible to stabilize the composition and structural - mechanical properties of the products as well as to obtain high quality of finished products.

Structural-mechanical or rheological properties are studied during the deformation and destruction of any types of products in the process of mechanical loading thus the resulting effects of resistance to the loads acting on them are investigated.
The study of the deformation of flour confectionery products makes it possible to identify both the quantitative relationship between the deformation and the strain rate as well as the molecular kinetic phenomena that occur during their deformation.

The following indicators were determined in the experimental and control samples of green tea sponge cake: total deformation ( $\mathrm{H}$ total), plastic deformation $(\mathrm{H}$ square), elastic deformation $\mathrm{H}$ (elastic) 1 hour after baking. The results are shown in Table 5.

Table 5. The results of the determination of rheological.

\begin{tabular}{|c|c|c|c|}
\hline Sample & Htot $\mathbf{~ m m}$ & Hsq, $\mathbf{~ m m}$ & Hel, $\mathbf{~ m m}$ \\
\hline Control sample & 12.992 & 4.883 & 8.109 \\
\hline $\begin{array}{c}\text { Sample with Sencha } \\
\text { Fukamushi Tea }\end{array}$ & 11.954 & 4.738 & 6.842 \\
\hline $\begin{array}{c}\text { Sample with Shu } \\
\text { Xiang Lu tea }\end{array}$ & 10.858 & 4.704 & 6.238 \\
\hline
\end{tabular}

Samples had fairly good structural and mechanical properties which are consistent with their organoleptic properties. Such rheological values will provide a good digestion of sponge cake with green tea by the human body.

To justify the storage capacity of the sponge cake the indicator "water activity" was studied. It characterizes the microbiological growth of microorganisms, shows the intensity of the flow of chemical processes and affects the texture and shelf life of confectionery products. Regarding this indicator a high-quality and safe product will be produced.

The water activity indices of the produced sponge cake were determined on 1,5,7,10 and 13 days of storage. The research results are presented in Fig. 3.

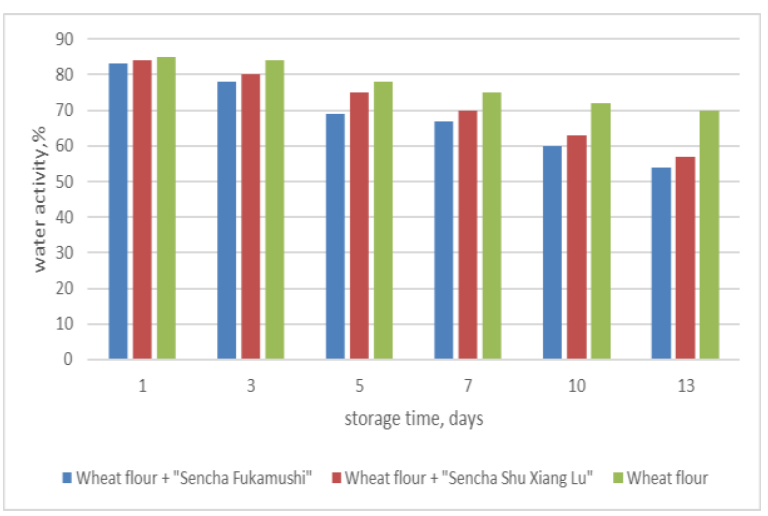

Fig. 3. Dynamics of water activity in sponge cake.

It was found that on the 3rd day of storage the sample of the sponge cake with both sorts of green tea reaches a safe value of the "water activity" parameter. During storage there are no sharp changes in this indicator which shows shrinkage and a favorable microbiological background.

Shelf life of sponge cake with green tea semifinished products was determined in accordance with the requirements of MUK 4.2.1847-04 for the expected shelf life (10 days) considering a reserve ratio of 1.3 . The target dates were selected with the required frequency production date and then after 5, 7, 10 and 13 days. The 
results of microbiological parameters during the experimental shelf life of semi-finished products are shown in Table 6-8.

Table 6. Change in sanitary-indicative microflora of sponge cake semi-finished products with the addition of Sencha

Fukamushi green tea during storage, $(18 \pm 2)^{\circ} \mathrm{C} ; 13$ days.

\begin{tabular}{|c|c|c|c|c|c|c|}
\hline \multirow[b]{2}{*}{$\begin{array}{l}\text { Type } \\
\text { of } \\
\text { culture }\end{array}$} & \multicolumn{5}{|c|}{ Duration of storage, days } & \multirow{2}{*}{$\begin{array}{c}\text { MI } \\
\text { indicators } \\
4.2 .1847-0 \\
4\end{array}$} \\
\hline & $\begin{array}{l}\text { productio } \\
\text { n day }\end{array}$ & 5 & 7 & 10 & 13 & \\
\hline $\begin{array}{c}\text { APC, } \\
\text { CFU / } \\
\text { g }\end{array}$ & 158 & $\begin{array}{c}25 \\
1\end{array}$ & $\begin{array}{c}67 \\
4\end{array}$ & $\begin{array}{c}84 \\
0\end{array}$ & $\begin{array}{c}2 \cdot 10 \\
3\end{array}$ & $\begin{array}{c}\text { no more } \\
\text { than } 5 \cdot 103\end{array}$ \\
\hline $\begin{array}{c}\text { Yeast } \\
\text { CFU / } \\
\mathrm{g}\end{array}$ & 10 & 19 & 21 & 35 & 40 & $\begin{array}{l}\text { no more } \\
\text { than } 50\end{array}$ \\
\hline $\begin{array}{l}\text { Mold. } \\
\text { CFU / } \\
\text { g }\end{array}$ & 15 & 29 & 35 & 43 & 47 & $\begin{array}{l}\text { no more } \\
\text { than } 50\end{array}$ \\
\hline E. coli & \multicolumn{5}{|c|}{ Not found } & $\begin{array}{c}\text { not found } \\
0.1 \mathrm{~g}\end{array}$ \\
\hline $\begin{array}{c}\text { S.aureu } \\
\mathrm{s}\end{array}$ & \multicolumn{5}{|c|}{ Not found } & $\begin{array}{l}\text { not found } \\
\text { in } 0.1 \mathrm{~g}\end{array}$ \\
\hline
\end{tabular}

Table 7. Change in the sanitary-indicative microflora of sponge cake semi-finished products with the addition of Shu

Xiang Lu green tea during storage, $(18 \pm 2)^{\circ} \mathrm{C} ; 13$ days.

\begin{tabular}{|c|c|c|c|c|c|c|}
\hline \multirow[b]{2}{*}{$\begin{array}{l}\text { Type of } \\
\text { culture }\end{array}$} & \multicolumn{5}{|c|}{ Duration of storage, days } & \multirow{2}{*}{$\begin{array}{c}\text { MI } \\
\text { indicators } \\
4.2 .1847-0 \\
4\end{array}$} \\
\hline & $\begin{array}{l}\text { productio } \\
\text { n day }\end{array}$ & 5 & 7 & 10 & 13 & \\
\hline $\begin{array}{c}\mathrm{APC}, \\
\mathrm{CFU} / \\
\mathrm{g}\end{array}$ & 154 & $\begin{array}{c}25 \\
6\end{array}$ & $\begin{array}{c}72 \\
0\end{array}$ & $\begin{array}{c}92 \\
0\end{array}$ & $\begin{array}{c}3 \cdot 10 \\
3\end{array}$ & $\begin{array}{l}\text { no more } \\
\text { than } 5 \cdot 103\end{array}$ \\
\hline $\begin{array}{c}\text { Yeast } \\
\text { CFU / } \\
\mathrm{g}\end{array}$ & 11 & 24 & 25 & 42 & 47 & $\begin{array}{l}\text { no more } \\
\text { than } 50\end{array}$ \\
\hline $\begin{array}{l}\text { Mold. } \\
\text { CFU / } \\
\mathrm{g}\end{array}$ & 16 & 31 & 37 & 45 & 49 & $\begin{array}{c}\text { no more } \\
\text { than } 50\end{array}$ \\
\hline E. coli & & & foun & & & $\begin{array}{l}\text { not found } \\
\text { in } 0.1 \mathrm{~g}\end{array}$ \\
\hline $\begin{array}{c}\text { S.aureu } \\
\text { s }\end{array}$ & & & foun & & & $\begin{array}{c}\text { not found } \\
0.1 \mathrm{~g}\end{array}$ \\
\hline
\end{tabular}

It was revealed that according to microbiological indicators - APC and sanitary-indicative microflora (E. coli, Staphylococcus aureus, mold and yeast) sponge cakes with green tea meet the standards within all control periods.

The results of the calculation of the nutritional value of sponge cake with green tea samples (Table 8) confirmed the feasibility of using green tea in the technology of sponge cake confectionery.
Table 8. Nutritional value of cupcakes (per $100 \mathrm{~g}$ of product).

\begin{tabular}{|c|c|c|c|c|}
\hline Product & $\begin{array}{c}\text { Protein } \\
\text { s, g }\end{array}$ & $\begin{array}{c}\text { Fats } \\
, \mathbf{g}\end{array}$ & $\begin{array}{c}\text { Carbohydrate } \\
\mathbf{s , g}\end{array}$ & $\begin{array}{c}\text { Caloric } \\
\text { content, } \\
\text { kcal }\end{array}$ \\
\hline $\begin{array}{c}\text { Sponge } \\
\text { cake }\end{array}$ & 8 & 5 & 46 & 260 \\
\hline $\begin{array}{c}\text { Sponge } \\
\text { cake with } \\
\text { green tea }\end{array}$ & 8 & 5 & 45 & 255 \\
\hline
\end{tabular}

The content of mineral elements and vitamins in the sponge cake baked according to the new technology with the addition of green tea is presented in Table $(9-10)$.

Table 9. The content of mineral elements and vitamins in a sponge cake with the green tea "Sencha Fukamushi".

\begin{tabular}{|c|c|c|c|}
\hline Name & $\begin{array}{c}\text { Norm } \\
\text { (FAO), } \\
\text { mg }\end{array}$ & $\begin{array}{c}\text { Content in } \\
\mathbf{1 0 0} \text { g of } \\
\text { sponge } \\
\text { cake, } \mathbf{~ m g}\end{array}$ & $\begin{array}{c}\text { \% of the } \\
\text { norm in } \\
\mathbf{1 0 0} \text { g }\end{array}$ \\
\hline \multicolumn{4}{|c|}{ Minerals: } \\
\hline Calcium & 1000.00 & 42.38 & 4.20 \\
\hline Magnesium & 400.00 & 19.26 & 4.82 \\
\hline Sodium & 1300.00 & 73.54 & 5.66 \\
\hline Potassium & 2500.00 & 141.78 & 5.67 \\
\hline Phosphorus & 800.00 & 125.14 & $\mathbf{1 5 . 6 4}$ \\
\hline Iron & 18.00 & 3.58 & $\mathbf{1 9 . 8 9}$ \\
\hline \multicolumn{4}{|c|}{ Vitamins: } \\
\hline Vitamin A & 0.90 & 0.16 & $\mathbf{1 7 . 7 8}$ \\
\hline Vitamin PP & 20.00 & 2.15 & 10.75 \\
\hline $\begin{array}{c}\text { Vitamin B_1 } \\
\text { (Thiamine) }\end{array}$ & 1.50 & 0.06 & 4.00 \\
\hline $\begin{array}{c}\text { Vitamin B_2 } \\
\text { (Riboflavin) }\end{array}$ & 1.80 & 0.28 & $\mathbf{1 5 . 5 6}$ \\
\hline $\begin{array}{c}\text { Vitamin B_4 } \\
\text { (Choline) }\end{array}$ & 500.00 & 132.15 & $\mathbf{2 6 . 4 3}$ \\
\hline $\begin{array}{c}\text { Vitamin C } \\
\text { ascorbic acid }\end{array}$ & 90.00 & 0.48 & 0.53 \\
\hline
\end{tabular}

Table 10. The content of mineral elements and vitamins in the sponge cake with the addition of green tea "Shu Xiang Lu".

\begin{tabular}{|c|c|c|c|}
\hline Name & $\begin{array}{c}\text { Norm } \\
\text { (FAO), } \\
\text { mg }\end{array}$ & $\begin{array}{c}\text { Content in } \\
\mathbf{1 0 0} \text { g of } \\
\text { sponge } \\
\text { cake, } \mathbf{~ m g}\end{array}$ & $\begin{array}{c}\text { \% of the } \\
\text { norm in } \\
\mathbf{1 0 0} \text { g }\end{array}$ \\
\hline \multicolumn{4}{|c|}{ Minerals: } \\
\hline Calcium & 1000.00 & 41.96 & 4.20 \\
\hline Magnesium & 400.00 & 18.12 & 4.53 \\
\hline Sodium & 1300.00 & 71.89 & 5.53 \\
\hline Potassium & 2500.00 & 139.76 & 5.59 \\
\hline Phosphorus & 800.00 & 122.05 & $\mathbf{1 5 . 2 6}$ \\
\hline Iron & 18.00 & 3.51 & $\mathbf{1 9 . 5 0}$ \\
\hline \multicolumn{4}{|c|}{ Vitamins: } \\
\hline Vitamin A & 0.90 & 0.15 & $\mathbf{1 6 . 6 7}$ \\
\hline Vitamin PP & 20.00 & 2.09 & 10.45 \\
\hline $\begin{array}{c}\text { Vitamin B_1 } \\
\text { (Thiamine) }\end{array}$ & 1.50 & 0.04 & 2.67 \\
\hline $\begin{array}{c}\text { Vitamin B_2 } \\
\text { (Riboflavin) }\end{array}$ & 1.80 & 0.26 & $\mathbf{1 4 . 4 0}$ \\
\hline $\begin{array}{c}\text { Vitamin B_4 } \\
\text { (Choline) }\end{array}$ & 500.00 & 130.00 & $\mathbf{2 6 . 0 0}$ \\
\hline $\begin{array}{c}\text { Vitamin C } \\
\text { ascorbic acid }\end{array}$ & 90.00 & 0.43 & 0.48 \\
\hline
\end{tabular}


It was found that when $100 \mathrm{~g}$ of sponge cake with green tea is consumed $15 \%$ of the daily requirement for phosphorus and $19 \%$ in iron are compensated. All these trace elements are one of the most important for the human body. The predominant among vitamins are vitamins A, B2 and B4, the content of which in the sponge cake makes up the daily need by 17,14 and $26 \%$ respectively.

\section{Conclusions}

The work defines technological aspects and shows the feasibility of using green tea powder in the production of sponge cake, a semi-finished product that does not require high gluten content in raw materials. The physicochemical parameters of Sencha green tea powder of two different manufacturers, wheat flour and also their mixtures in different percentages are studied. The results of the studies showed that green tea can be considered as a source of flavonoids and $\beta$-carotene in cooking flour confectionery products. Considering the water-binding and fat-binding abilities of the mixture, $12 \%$ of green tea powder to the weight of flour is taken as optimal for sponge cake semi-finished products.

The recipe and technology of sponge cake with green tea with the separate introduction of egg whites and egg yolks and brewing proteins with hot syrup were developed. It made it possible to obtain products with good organoleptic and structural-mechanical properties. Oven loss amounted to $21 \%$ is below the established standards. It was revealed that according to microbiological indicators and sanitary-indicative microflora sponge cake samples with green tea meet the standards within all control periods. Products with green tea have high nutritional value, enriched in phosphorus, iron, vitamins A and group B.

Technological documentation has been developed for a sponge cake with green tea. The introduction of the sponge cake technology proposed in the study into production will expand the range of flour confectionery products enriched with physiologically significant micronutrients.

\section{References}

[1] L. Nilova, T. Pilipenko, S. Malyutenkova, In investigation into the effects of bioactive substances from vegetable oils on the antioxidant properties of bakery products, Agronomy Research, 15, S2, 1399-1410 (2017).

[2] E. Moskvicheva, I. Timoshenkova, D. Chernikova, E. Fedinishina, M. Bernavskaya, Technology of biscuit semi-finished products using recycled pumpkin seeds, IOP Conference Series: Earth and Environmental Science, 337 (2019).

[3] V.R. Sinija, Green tea: Health benefits, Journal of Nutritional \& Environmental Medicine, 17, 4, 232-242 (2008).

[4] A. Maseka, E. Chrzescijanskab, A. Kosmalska, Antioxidant activity determination in Sencha and
Gun Powder green tea extracts with the application of voltammetry and UV-VIS spectrophotometry, Ref. Libr., 15, 5, 424-427 (2012).

[5] C. Dietz, M. Dekker, B. Piqueras-Fiszman, An intervention study on the effect of matcha tea, in drink and snack bar formats, on mood and cognitive performance, Ref. Libr., 99, 1, 72-83 (2017).

[6] B. Phongnarisorn, C. Orfila, M. Holmes, Enrichment of Biscuits with Matcha Green Tea Powder: Its Impact on Consumer Acceptability and Acute Metabolic Response, Ref. Libr., 7, 2, 116-118 (2018).

[7] S.N. Edygova, Wheat bread development using green tea infusion, In the collection: Improving the quality and safety of foodstuff Materials of the VIII All-Russian Scientific and Practical Conference, 151-152 (2018).

[8] C. Yan-Hwa, C. Chao-Lin, H. Hsia-Fen, Flavonoid content of several vegetables and their antioxidant activity, J. Sci. Food Agric, 80, 561566 (2000).

[9] AOAC, Official methods of analysis, Association of Official Analytical Chemists, Inc., Washington, DC, USA (2015).

[10] GOST 5669-96, Bakery products, Method for determination of porosity (1996) (in Russian).

[11] Methodological instructions MI 4.2.1847 - 04 Sanitary and epidemiological assessment of the justification of expiration dates and storage conditions for foodstuffs (2004) (in Russian).

[12] TRCU, Technical regulation of the Customs Union, Food safety, 021/2011 (2011) (in Russian).

[13] C.S. James, Analytical chemistry of foods, Glasgow: Blackie Academic and Professional, 192 (1995) 